\title{
AGENDA STANDARDNÍHO SPECIFICKÉHO VÝZKUMU FAST VUT V BRNĚ
}

\section{AGENDA OF STANDARD SPECIFIC RESEARCH FACULTY OF CIVIL ENGINEERING BRNO UNIVERSITY OF TECHNOLOGY}

\author{
Rostislav Doubek ${ }^{*}, 1$
}

*doubek.r@fce.vutbr.cz

${ }^{1}$ Fakulta stavební VUT v Brně, Veveří 331/95, Brno, 60200

\begin{abstract}
Abstrakt
Cílem tohoto př́spěvku je seznámit čtenáře s průběhem agendy standardního specifického výzkumu Fakulty stavební, Vysokého učení technického v Brně, a to od podání žádosti, přes průběh vlastního výzkumu až po věcné a administrativní naplnění požadavků výzkumu.

Součástí řešení výzkumného projektu není pouze myšlenka a výzkumná část ale i související administrativní náležitosti, které mohou být v některých ohledech i náročnější než vlastní výzkum.

Níže popsaný postup by měl začínajícímu vědeckému pracovního pomoci se snadněji zorientovat v problematice administrativních kroků a fází výzkumu, a tím propojení standardizovaných správních úkonů s vědeckým potenciálem.
\end{abstract}

\section{Klíčová slova}

Specifický výzkum, administrativa projektu, výzkumná fáze, věžové jeřáby, financování projektu

\section{Abstract}

The aim of this paper is to acquaint readers with the course of the standard specific research agenda of the Faculty of Civil Engineering, Brno University of Technology, from the application, through the course of their own research to the factual and administrative fulfillment of research requirements.

The solution of the research project includes not only the idea and the research part, but also the related administrative requirements, which can be in some respects even more demanding than the research itself.

The procedure described below should make it easier for the beginning scientific work assistance to orientate themselves in the issues of administrative steps and research phases, and thus link standardized administrative tasks with scientific potential.

\section{Key words}

Specific research, project administration, research phase, tower cranes, project financing

\section{1 ÚVOD}

Tento článek podrobně popisuje metodický a chronologický postup při přípravě a plnění výzkumného projektu, konkrétně jde o specifický standardní výzkum Fakulty stavební Vysokého učení technického v Brně.

Postup bude uveden na konkrétním výzkumném projektu pro snadnější představu čtenáře, jak danou problematiku řešit a jak postupovat.

Prvořadým krokem je připravit si téma pro vědecký záměr (projekt), který bude řešen. Následuje podání žádosti o přidělení výzkumné podpory, především finančních prostředků pro zpracování projektu. Poté vědecká komise posoudí vědecký záměr na základě předložené žádosti. Po schválení projektu prristoupí řešitel ke zpracovávání jednotlivých částí svého projektu. Nakonec proběhnou administrativní činnosti v podobě plnění financování projektu, předložení dosažených a získaných výsledků či produktů se závěrečnou výzkumnou zprávou. 


\section{LITERÁRNÍ PŘEHLED/POPIS SOUČASNÉHO STAVU}

Obecně se specifickým výzkumem na Fakultě stavební zabývá každý vědecký pracovník, který v rámci vědeckého záměru o projekt zažádá.

V rámci př́ikladového tématu výzkumu, kterým je stavebně technologická výkonnost věžových jeřábů a vývoj aplikace pro návrh jeřábů, jsou v průběhu let řešeny tématiky obsažené $\mathrm{v}$ článcích Optimalizace návrhu věžových jeřábů: př́ispěvek $\mathrm{k}$ modelování výrobního prostoru stavby doc. V. Motyčky a Časové posouzení využití zdvihacích mechanismů v pozemním stavitelství dr. M. Štěrby. První známý software vzniklý na základě dat získaných v rámci českého stavebnictví, resp. aplikace, která umožňuje návrh věžového jeřábu v rámci stavebně technologického projektování je „Časové vytížení stavebních jeř́bưu“ vzniklý na základě specifického výzkumu standardního FAST-S-18-5286 z roku 2018 [1], [2].

\section{METODIKA}

Vlastní chronologický postup řešení výzkumného projektu by se dal rozdělit do osmi zásadních fází, které mají své další př̌islušné kroky pro naplnění všech stěžejních aspektů agendy výzkumu, která je obdobná i pro jiné typy řešených projektů.

V první fázi dojde ze strany vedení fakulty $\mathrm{k}$ vyhlášení "soutěže", tedy $\mathrm{k}$ vyhlášení Specifického vysokoškolského výzkumu. V rámci této výzvy jsou rozlišovány dva typy, a to standardní a juniorský.

O možnosti vyhlášení soutěže stanovuje rozhodnutí rektora (č. 12/2020 v platném znění) a to vyhlášením soutěže na podporu projektů specifického školského výzkumu na VUT v Brně pro př̌slušný rok. Dokument uvádí na základě, které právní normy je soutěž vyhlášena, stanovuje termíny pro pořádání soutěže, zahájení řešení projektů a hodnocení projektů. Druhým stěžejním dokumentem je směrnice univerzity, a to č. 14/2019 o zásadách studentské grantové soutěže na podporu projektů specifického vysokoškolského výzkumu na VUT. Ten mimo jiné udává úkoly, činnost a organizační strukturu grantové agentury VUT, pravidla studentské grantové soutěže.

Oba dokumenty dále hovoří o metodice prípravy žádosti, definici druhů výsledků a informací ke specifickému výzkumu.

Druhou fází př́mo navazující na první je stanovení vědeckého záměru a jeho téma a to například: Hlavním cílem projektu je vypracovat metodiku pro posouzení technologické výkonosti věžových jeřábů a jejich soustav při výstavbě výškových budov ze železobetonových monolitických konstrukcí.

Dílčími cíli bude monitoring výstavby výškové budovy a následná komparace teoretických a naměřených hodnot vstupních dat, dále analyzovat a určit vhodné stroje pro tuto činnost, typové pracovní cykly věžových jeřábů u vybraných dílčích stavebních procesů při výstavbě výškových budov, analyzovat moderní způsoby ř́zení a koordinace práce soustavy věžových jeřábů, definování okrajových podmínek a príprava vstupních dat pro vytvoření simulačního modelu.

Dále vytvoření simulačního modelu pro posouzení technologické výkonnosti soustavy věžových jeřábů a jeho softwarové zpracování pro využití výpočetní technikou.

Následuje třetí fáze podání žádosti schvalovací komisi. Tato žádost obsahuje nejen myšlenku projektu ale i důležitý administrativně primární předpoklad zrealizování projektu, což je financování projektu.

Žádost tedy obsahuje název projektu, tým (hlavní řešitel a spoluřešitelé), anotaci projektu, současný stav poznání, cíle projektu, metody řešení, postup řešení, rámcový plán disertačních prací a jejich soulad s vědeckým záměrem projektu, program mezinárodní spolupráce, předpokládané výstupy a finanční prostředky.

Postup řešení uvádí, že projekt bude probíhat $\mathrm{v}$ sedmi etapách. Předpokládanými výstupy jsou články v impaktovaných a neimpaktovaných časopisech, odborné knihy, př́spěvky na konferencích, diplomové a disertační práce, přihlášky patentů a užitných nebo průmyslových vzorů, software a zavedená technologie. Druh a počet výstupů si stanovuje řešitel při podání žádosti.

Finanční prostředek pro zrealizování projektu je dán celkovým finančním objemem. Ten se skládá z věcných materiálových nákladů (materiál pro výzkum, drobné výdaje), služeb (služby včetně překladů, vložné na konference), cestovného (konzultace, konference), stipendií (pro studenty), mezd (pro zaměstnance) a režií (pro fakultu).

Věcné materiálové náklady až cestovné stanovuje řešitel na základě tématu, stipendia a mzdy vychází z poměrového rozložení spoluřešitelů (počet zaměstnanců vůči studentům) a režie jsou dány "full-costem" a je stanovena ve výši 26,85 procent. Na základě projednání ve Vědecké komisi AS FAST byl nastaven minimální poměr osobních nákladů mezi studenty a vědeckopedagogickými pracovníky na poměr $80: 20 \mathrm{~s}$ cílem více podpořit studenty (Směrnice rektora uvádí poměr $75: 25$, fakulta jej však může upravit).

Se třetí fází je úzce spjatá čtvrtá fáze, ve které je nutné provést zadání projektu do výzkumné intranetu informačního systému VUT (Apollo). Obr. 1 Ilustrace aplikace Apollo. 
V rámci karty "výzkum a vývoj" část "projekt" řešitel založi projekt a postupně vyplňuje veškeré potřebné údaje z kategorií základní údaje (identifikace projektu), doplňující údaje (projektu), programy financování (informace o financování), řešitelé (osoby zapojené do projektu), řešitelské týmy (nastavení struktury týmů), obory (zaměření projektu dle oboru), fakultní hodnocení (interní fakultní hodnocení), související projekty a vlastnosti záznamu (projektu).

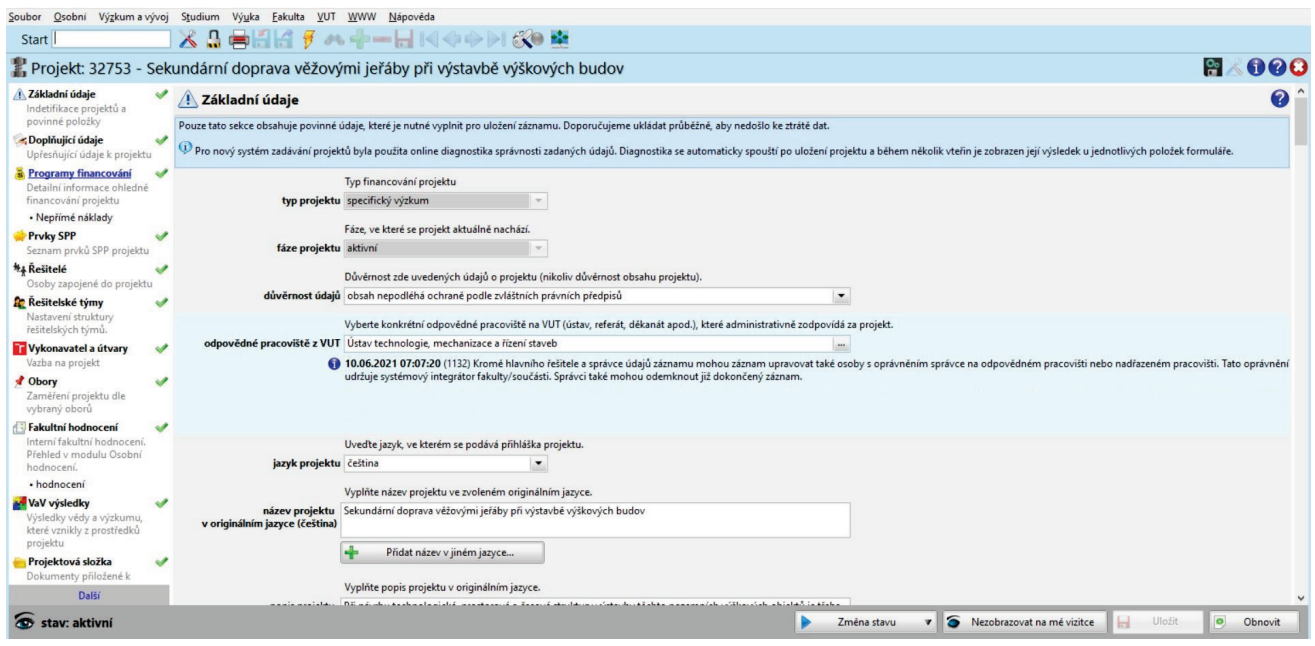

Obr. 1 Ilustrace aplikace Apollo.

Pátou fází je schválení žádosti a uzavření smlouvy mezi řešitelem a fakultou. Předmětem smlouvy je splnění řešitelského závazku v rámci výzkumného záměru při dodržení podmínek, které stanovují rozhodnutí a směrnice rektora výše uvedené.

Řešení vlastního projektu je šestou fází. Jedná se o vlastní vědecké řešení vybraného výzkumného záměru, který je předmětem smluvního vztahu. V rámci projektu je nutné mít naplánovány jednotlivé etapy výzkumu ale i časový plán (odkaz na Obr. 2 Př́iklad časového plánu řešení projektu.) a čerpání financí (odkaz na Obr. 3 Příklad plánu čerpání financí.).

První etapou je rešeršní činnost současného stavu řešené problematiky a vstupní prvky výzkumu. Konkrétně jde o technologie výstavby výškových budov v České republice a ve světě, obecně a podle konstrukce, príípadové studie technologie výstavby, řešení technologické, prostorové a časové struktury, typy věžových jeřábů pro výškové budovy a jejich možnosti využití, př́ípadové studie využití věžových jeřábů a způsoby jejich řízení a koordinace na reálné stavbě, rešerše a analýza moderních způsobů řízení a koordinace soustav věžových jeřábů, průzkum a analýza možnosti využití existujících simulačních modelů a softwarů pro řešení úkolu, bezpečnostní předpisy pro věžové jeřáby a jejich soustavy.

Ve druhé etapě jsou řešeny vstupní data a okrajové podmínky řešení pro výpočtový model, určení a rozbor rozhodujících dílčích stavebních procesů a okrajových podmínek pro modelování práce věžových jeřábů při výstavbě výškových budov a jejich požadavky na obsluhu věžovým jeřábem, rozbor pracovních cyklů věžových jeřábů pro jednotlivé dílčí stavební procesy, typový pracovní cyklus věžových jeřábů pro výškové budovy [3].

Třetí etapa zahrnuje monitoring výstavby, metodika experimentálního sledování včetně třídění a archivace pořizených a zpracovaných podkladů, experimentální sledování obsluhy dílčích stavebních procesů s prací věžových jeřábů, vyhodnocení naměřených dat jednotlivých dílčích stavebních procesů a jejich srovnání s teoretickými výpočty doby typického pracovního cyklu [4].

Čtvrtou etapou je stanovení metodiky pro posouzení technologické výkonosti věžových jeřábů, technologická výkonnost věžových jeřábů při provádění železobetonových monolitických konstrukcí výškových objektů, zděných konstrukcí a lehkých obvodových pláštů, prííprava vstupních dat pro matematický model, posouzení technologické výkonnosti věžových jeřábů na stavbě železobetonových konstrukcí výškového objektu, posouzení výkonnosti s ohledem na druhy věžových jeřábů, posouzení výkonnosti soustavy věžových jeřábů, návrh metodiky pro posouzení technologické výkonosti věžových jeřábů a jejich soustav při výstavbě výškových budov ze železobetonové monolitické konstrukce.

$\mathrm{V}$ páté etapě je řešen simulační model. Vytvoření simulačního matematického modelu práce soustavy věžových jeřábů, vycházejícího ze stanovených okrajových podmínek, vstupních dat a typových pracovních cyklů rozhodujících dílčích stavebních procesů, pro posouzení technologické výkonnosti soustavy věžových jeřábů v návaznosti na smluvní časový plán výstavby. 
Šestá etapa vytvárí výpočetní program pro posouzení technologické výkonnosti soustavy věžových jeřábů v návaznosti na vytvořený simulační model následuje počítačové zpracování tohoto modelu, vytvoření algoritmu a výpočetního programu.

Poslední sedmá etapa vyžaduje ověření výpočetního programu na monitorované výškové budově. Pilotní ověření metodiky pro výškové budovy a pilotní ověření metodiky pro soustavy věžových jeřábů.

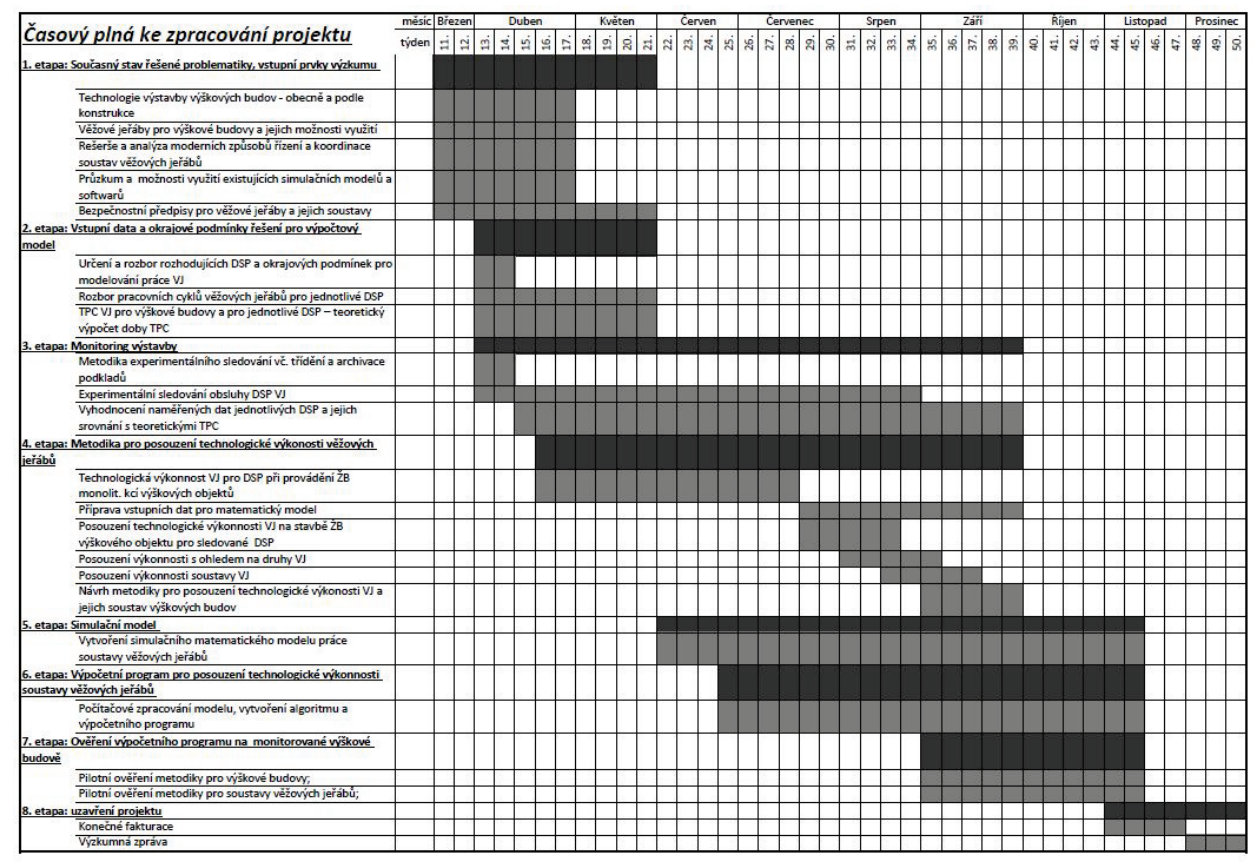

Obr. 2 Př́iklad časového plánu řešení projektu.

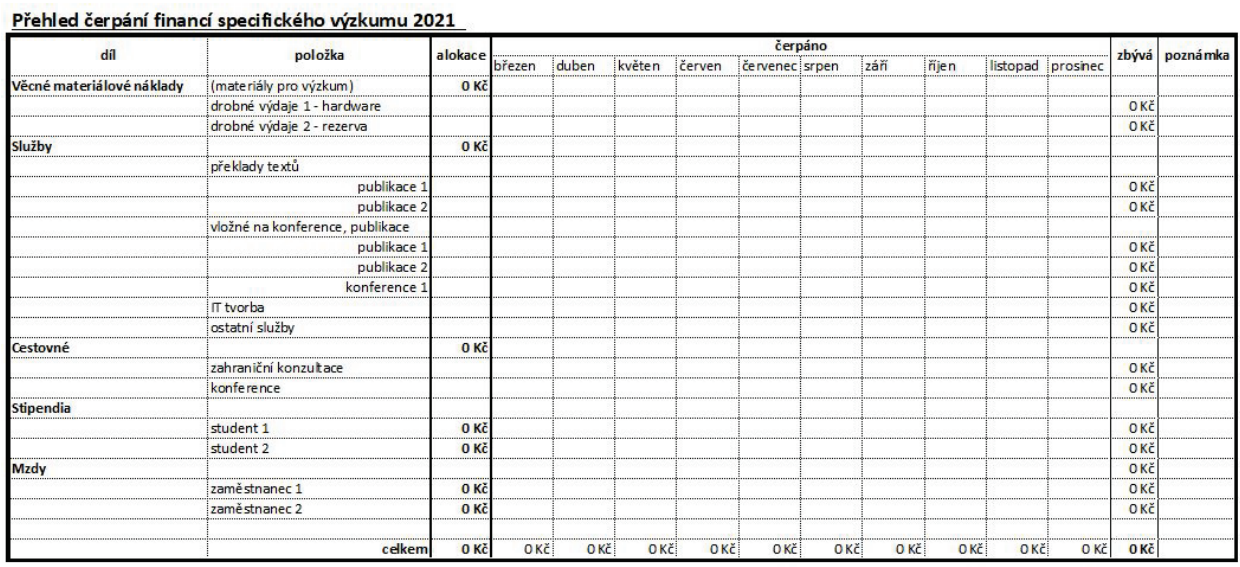

Obr. 3 Př́íklad plánu čerpání financí.

Sedmá fází řeši splnění závazku projektu, a to nejen věcné splnění výzkumné činnosti ale i výstupů (odkaz na Obr. 4 Přehled výstupů výzkumu.), ke kterým se řešitel zavázal. 
Přehled výstupů specifického výzkumu 2021

\begin{tabular}{|l|l|l|l|l|}
\hline \multicolumn{1}{|c|}{ položka } & \multicolumn{1}{|c|}{ specifikace } & slíbeno & splněno & poznámka \\
\hline článek & neimpaktovaný-Buildustry & ano & & do 26.11.2021 \\
\hline článek-konference & Scopus -WMCAUS 21 & ano & ano & \\
\hline článek-konference & Juniorstav & ano & & do 28.11.2021 \\
\hline článek-konference & Juniorstav & ano & ano & \\
\hline software & & ano & & do 30.12.2021 \\
\hline
\end{tabular}

Obr. 4 Přehled výstupů výzkumu.

Poslední osmou fází projektu je splnění administrativních požadavků, což zahrnuje prokázání splnění cíle řešeného projektu, vytvoření výstupů, vyčerpání finančních prostředků a vyhotovení výzkumné zprávy projektu.

\section{ZÁVĚR}

Tento příspěvek měl za cíl seznámit začínající studenty doktorského programu s možností využití finanční podpory v rámci univerzitního grantu pro vědeckou výzkumnou činnost.

Výše popsaná metodika pomáhá se snadněji orientovat v administrativním postupu i faktickém př́istupu řešení vědeckého projektu.

Přínosem je především pro začínající studenty a vědecké pracovníky, kteří se chtějí pro svoji vědeckou činnost využít i jiných, než pouze vlastních finančních prostředků.

\section{Poděkování}

Tato publikace i zmíněná aplikace jsou vytvořeny na základě podpory ze specifického výzkumu standardního 2021 FAST-S-21-7374.

\section{Použité zdroje}

[1] Motyčka, V.: Optimalizace návrhu věžových jeřábů, Ústav technologie, mechanizace a řízení staveb, Fakulta stavební, Vysoké učení technické v Brně, Česká republika 2007.

[2] Štěrba, M.: Časové posouzení využití zdvihacích mechanismů v pozemním stavitelství, Ústav technologie, mechanizace a řízení staveb, Fakulta stavební, Vysoké učení technické v Brně, Česká republika, 2021.

[3] Doubek, R.: Sledování nasazení zvedacích prostředků pro ŽB sloupy. In Juniorstav 2019, 21. odborná konference doktorského studia s mezinárodní účastí. Brno: ECON publishing, s. r. o., s. 99-104. ISBN: 978-80-86433-71-4. Česká republika, 2019.

[4] Doubek, R.: Prostředky terénního měření a správa dat při sledování nasazení zvedacích prostředků. In Juniorstav, 22. odborná konference doktorského studia s mezinárodní účastí. Brno: ECON publishing, s. r. o., 2020. s. 138-143. ISBN: 978-80-86433-73-8. Česká republika, 2020. 